\title{
Two supratentorial meningiomas: are they different?
}

\author{
Osama S M Amin \\ Department of Neurology, Sulaimaniya General Teaching Hospital, Sulaimaniya City, Iraq
}

Correspondence to Dr Osama S M Amin, dr.osama.amin@gmail.com

\section{DESCRIPTION}

A 65-year-old woman comes for headache management. Few years ago, she was diagnosed with a 'single benign tumour of the anterior part of the brain'. A new contrast CT brain scan was done (figures 1 and 2); as she was claustrophobic, brain MRI was not ordered. The mass they have referred to was most likely a falcine meningioma. In addition, there is an oval hyperdense mass at the right temporal area, which is diffusely and homogenously calcified and seems to sit on the pertrous temporal bone, a finding that may well refer to another meningioma.

Multiple meningioma refers to the simultaneous (or sequential) appearance of two or more independently located meningiomas, not necessarily of the same pathological subtype 1 and without signs of neurofibromatosis type II. $^{2}$ Their incidence ranges from $1 \%$ to $10 \%$ of all meningiomas. They are more commonly found in the supratentorial compartment. The patient harbours a frontal falcine meningioma with a surrounding vasogenic oedema of the white matter. The right temporal meningioma's peritumoural area demonstrates no oedema. Counting on this oedema, one may presume that the former is a secretory, atypical or even malignant meningioma while the latter is a classical or typical meningioma. Souto et $a l^{3}$ found that two-thirds of their patients with intracranial meningioma demonstrated peritumoural oedema and that the site and size of the tumour were probably related to the development of this oedema. The patient's long history can exclude atypical/ malignant pathology. She has a classical temporal and a classical (or secretory) frontal meningiomas.

\section{Learning points}

- Although meningiomas are common intracranial tumours, multiple meningiomas are not, and the latter group is not necessarily part of neurofibromatosis type II.

- The mere presence of peritumoural oedema in meningiomas does not always refer to an atypical or malignant potential. Vascular endothelial growth factor is a key factor in the pathogenesis of these peritumoural oedemas, depending on the tumour site and size.

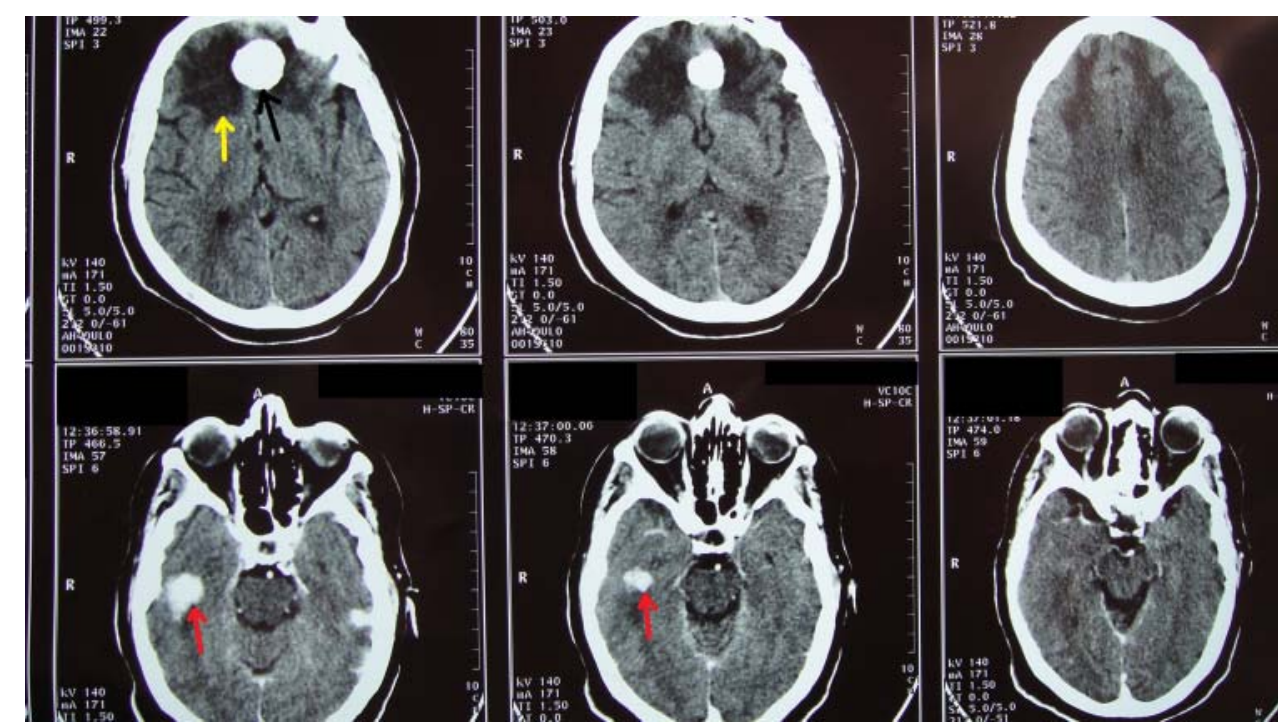

Figure 1 Contrast CT brain scanning of the patient. Note the frontal falcine rounded, diffusely, intensely and homogenously calcified mass (black arrow). In addition, there is a peritumoural vasogenic oedema of the frontal lobes' white matter (yellow arrow). This appearance may prompt the physician think of a secretory, atypical or malignant meningioma. The CT film also uncovers a similar but smaller oval- to tear-drop-shaped mass at the right temporal area (red arrow). The patient declined doing surgery and stereotactic brain biopsy is not available in Iraq, as well. No histopathological confirmation was done and claustrophobia precluded MRI examination; therefore, both masses were labelled as meningiomas depending on this imaging modality only. 


\section{BMJ Case Reports}

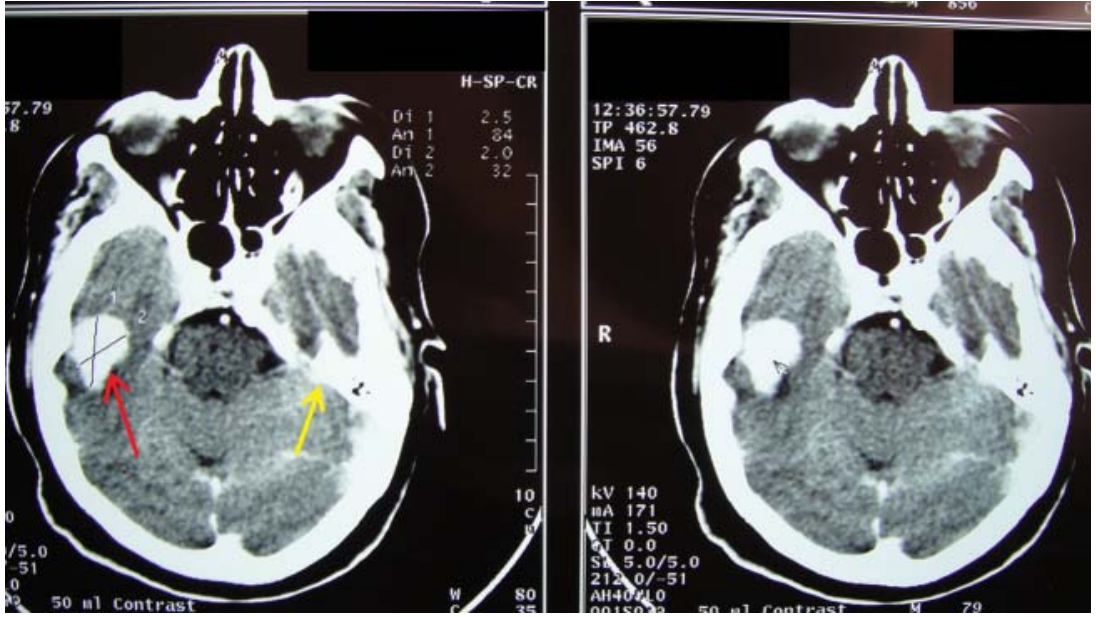

Figure 2 An enlarged axial CT brain scan film of the same patient at the level of the temporal lobes. Note how the oval hyperdense (most likely) meningioma (red arrow) at the right temporal area differs from the 'artefact' of the left temporal bone (yellow arrow). The mass sits on the lateral petrous temporal bone and abuts the inner aspect of the squamous temporal bone. The tumour has no surrounding oedema. This appearance may rise the suspicion of a skull base (bony) tumour or right temporal horn intraventricular meningioma.

\section{Competing interests None.}

\section{Patient consent Obtained.}

\section{REFERENCES}

1. Bhatoe HS. Simultaneous occurrence of multiple meningiomas in different neuraxial compartments. Neurol India 2003;51:263-5.
2. Gelabert-González M, Leira-Muiño R, Fernández-Villa JM, et al. Multiple intracranial meningiomas. Rev Neurol 2003;37:717-22.

3. Souto AA, Chimelli L, Takya CM, et al. Brain edema in meningiomas: radiological and histological factors. Arq Neuropsiquiatr 2002;60(3-B):807-17.

This pdf has been created automatically from the final edited text and images.

Copyright 2012 BMJ Publishing Group. All rights reserved. For permission to reuse any of this content visit http://group.bmi.com/group/rights-licensing/permissions.

BMJ Case Report Fellows may re-use this article for personal use and teaching without any further permission.

Please cite this article as follows (you will need to access the article online to obtain the date of publication).

Amin OSM. Two supratentorial meningiomas: are they different? BMJ Case Reports 2012;10.1136/bcr-2012-007177, Published XXX

Become a Fellow of BMJ Case Reports today and you can:

- Submit as many cases as you like

- Enjoy fast sympathetic peer review and rapid publication of accepted articles

- Access all the published articles

- Re-use any of the published material for personal use and teaching without further permission

For information on Institutional Fellowships contact consortiasales@bmjgroup.com

Visit casereports.bmj.com for more articles like this and to become a Fellow 